\title{
Cadmium-induced Oxidative Stress in Meretrix Meretrix Gills Leads to Mitochondria-mediated Apoptosis
}

Jinhua Wang

Wenzhou University

Wanfei Deng

Wenzhou University

Ting Zhou

Wenzhou University

Binbin Bai

Wenzhou University

Alan K. Chang

Wenzhou University

Xueping Ying ( $\nabla$ xpying2008@wzu.edu.cn )

Wenzhou University

\section{Research Article}

Keywords: Cadmium, Meretrix meretrix, Mitochondrial enzyme, Apoptosis, Mitochondrial membrane potential, Caspase

Posted Date: May 5th, 2021

DOI: https://doi.org/10.21203/rs.3.rs-475599/v1

License: (9) This work is licensed under a Creative Commons Attribution 4.0 International License. Read Full License

Version of Record: A version of this preprint was published at Ecotoxicology on September 16th, 2021. See the published version at https://doi.org/10.1007/s10646-021-02465-8. 


\section{Abstract}

Cadmium (Cd) is one of the most important marine environmental pollutants that can cause oxidative damage and apoptosis in living organisms, and mitochondria are the key target cell organelles of Cd toxicity. In this study, we investigated the effect of $\mathrm{Cd}$ on the mitochondria of Meretrix meretrix gill cells and the underlying mechanism of mitochondria-mediated apoptosis following exposure to the metal. Exposure of the clams to $1.5,3,6$ and $12 \mathrm{mg} \mathrm{L}^{-1} \mathrm{Cd}^{2+}$ solutions led to swollen mitochondria compared with the untreated clams. The mitochondria also became vacuolated at the higher $\mathrm{Cd}^{2+}$ concentrations. Biochemical assays showed that monoamine oxidase (MAO) activity and mitochondrial membrane potential $(\Delta \psi \mathrm{m})$ increased at $1.5 \mathrm{mg} \mathrm{L}^{-1} \mathrm{Cd}^{2+}$, but decreased at higher $\mathrm{Cd}^{2+}$ concentrations, while the activities of malate dehydrogenase (MDH) and cytochrome oxidase (CCO) and the scavenging capacities of anti-superoxide anion (ASA) and anti-hydroxy radical (AHR) all decreased with increasing $\mathrm{Cd}^{2+}$ concentrations. Significant increases in the levels of MDA and $\mathrm{H}_{2} \mathrm{O}_{2}$ as well as in the activity levels of caspase- $3,-8$, and -9 were also observed in the $\mathrm{Cd}^{2+}$-treated clams. The results implied that $\mathrm{Cd}$ might induce apoptosis in M. meretrix via the mitochondrial caspase-dependent pathway.

\section{Introduction}

In recent years, pollution caused by toxic metals has become a serious environmental problem that continues to increase in magnitude as a result of rapid industrialization and the massive use of fertilizers (Chen et al., 2020; Zhang and Gao, 2015). Among the toxic metals of concern is cadmium (Cd), which is widely distributed in aquatic ecosystems. Even at low concentrations, $\mathrm{Cd}$ is highly toxic to aquatic organisms because it is non-biodegradable and it has a long biological half-life (Capriello et al., 2019; Park et al., 2020), and therefore, it can accumulate in the food chain, causing tissue injury and threatening the health of aquatic animals (Chen et al., 2020; Jing et al., 2019; Pan et al., 2018). At the cellular level, $\mathrm{Cd}$ also has the potential to affect cellular antioxidant defenses and damage the DNA repair systems, indicating that Cd plays a vital role in apoptosis (Lin et al., 2017; Park et al., 2020; Xia et al., 2016).

Mitochondria are the key intracellular targets for Cd stress (Bhansali et al., 2017), and Cd exposure can damage the integrity of the mitochondria in aquatic organisms, both structurally and functionally (Adiele et al., 2011). Ji et al. (2019) found that Cd can induce the reconstruction of energy homeostasis, stress resistance and apoptosis in Ruditapes philippinarum, and suggested that mitochondria are the key target of $\mathrm{Cd}$ toxicity in clams. Monoamine oxidase (MAO), malate dehydrogenase (MDH) and cytochrome oxidase (CCO) are the key enzymes of mitochondria. Cd can affect the activities of all these three enzymes (Achard-Joris et al., 2006; Goswami et al., 2014; Wu et al., 2015). Mitochondria are a major source of superoxide radical $\left(\mathrm{O}_{2}{ }^{--}\right)$and hydrogen peroxide $\left(\mathrm{H}_{2} \mathrm{O}_{2}\right)$ in a cell (Bhansali et al., 2017), and Cd has been shown to facilitate the formation of reactive oxygen species (ROS) by interfering with the electron transport chain in the mitochondria, consequently stimulating lipid peroxidation via the oxidation of polyunsaturated fatty acids in organisms such as the bivalves (Goswami et al., 2014; Ji et al., 2019). 
Through the electron transport chain of the mitochondria, $\mathrm{O}_{2}{ }^{\cdot-}$ generates $\mathrm{H}_{2} \mathrm{O}_{2}$, which is then split by catalase into water and oxygen or is partially reduced to hydroxide radical $(\cdot \mathrm{OH})$ in a Fenton reaction, causing a wider cellular oxidative damage (Feng et al., 2014). A high level of ROS such as $\cdot \mathrm{OH}, \mathrm{H}_{2} \mathrm{O}_{2}$, and $\mathrm{O}_{2}{ }^{--}$in mitochondria can result in the attack of membrane phospholipids by free radicals. The loss of mitochondrial membrane potential (MTP, $\Delta \psi \mathrm{m}$ ) can cause the alteration of mitochondrial membrane permeability, leading to the release of cytochrome c (Cyt c) and subsequent stimulation of intracellular caspase- 8 and caspase- 9 , followed by the induction of caspase- 3 and initiation of apoptosis (AchardJoris et al., 2006; Đukić-Ćosić et al., 2020; Liu et al., 2013; Zhao et al., 2015). The activation of caspases can be considered a crucial mechanism of Cd-induced apoptosis. Wallace et al. (2019) suggested that a decrease in mitochondrial membrane permeability in hepatic cells exposed to $\mathrm{Cd}$, as well as an increase in both caspase-3 and caspase-9 activities, can directly lead to programmed cell death. Cadmium can interfere with apoptotic pathways, which converge on the activation of caspase-3, eventually culminating in cellular fragmentation and cell death (Đukić-Ćosić et al., 2020).

Bivalves are widely distributed in the water ecosystem. As these animals are filter feeders with poor locomotion ability, they are rather sensitive to the contamination of the aquatic environment by toxic metals, making them a group of important animals for aquatic toxicology research and for the evaluation of pollution by toxic metals (Chandurvelan et al., 2015; Chen et al., 2020; Ji et al., 2019). The clam Meretrix meretrix is one of the important cultivated conventional marine bivalves in China, because of its economic and ecological importance. Meretrix meretrix has been gradually used as a suitable bioindicator of toxic metal pollution in recent years (Alyahya et al., 2011; Wan et al., 2018). Bivalve gills are the main target organs for the accumulation of metals, and they usually show the highest level of pollutants (Jing et al., 2019; Trevisan et al., 2014). Our previous study has shown that the accumulation of $\mathrm{Cd}$ in the gills of M. meretrix is the highest when compared with three other tissues (Huang et al., 2020). This is due to their role in nutrient uptake, respiration, and their close contact with the incoming water (Jing et al., 2019). The gill is also the main barrier against environmental pollutant injury and pathological agents, making it the first site where the injury caused by toxic metals is likely to occur (Huang et al., 2020; Marasinghe Wadige et al., 2017). Oxidative damage and apoptosis in clams resulting from $\mathrm{Cd}$ toxicity have been confirmed by numerous morphological and biochemical studies (Achard-Joris et al., 2006; Huang et al., 2020; Ji et al., 2019; Xia et al., 2016). However, the mechanism associated with the apoptotic process that is trigged by Cd-induced oxidative stress was not elucidated in these studies. The present study investigated the mitochondria-associated apoptosis in $M$. meretrix gill cells following exposure to $\mathrm{Cd}$. Changes in mitochondrial structure, anti-free radical capacity and apoptosis-related factors between untreated and Cd-treated $M$. meretrix individuals were determined and compared. The study aimed to explore the effect of $\mathrm{Cd}$ on cellular oxidative damages in the mitochondria of M. meretrix gills, and to identify the underlying mechanism of the mitochondria-mediated apoptotic pathway in $M$. meretrix gill induced by $\mathrm{Cd}$.

\section{Materials And Methods}




\subsection{Animals and teatments}

Meretrix meretrix used in the experiment was purchased from Lingkun aquafarm in Zhejiang Province. The average length, width and height of these clams were $52.72 \pm 2.20 \mathrm{~mm}, 26.95 \pm 1.26 \mathrm{~mm}$, and 43.41 $\pm 1.88 \mathrm{~mm}$, respectively, and their average weight was $39.06 \pm 4.81 \mathrm{~g}$. The concentration of cadmium, time of exposure and the method of exposure used were as previously described (Xia et al., 2016). After 5 days of exposure to $\mathrm{Cd}^{2+}$, all the clams were dissected and the gills were quickly removed and immediately fixed in glutaraldehyde or paraformaldehyde, or frozen in liquid nitrogen and then stored in a $-80^{\circ} \mathrm{C}$ freezer until analysis.

\subsection{Morphological analysis by histology and transmission electron microscopy}

In order to determine the histological morphology of the gill filaments, the gills from the control and exposed clams were fixed in $4 \%(\mathrm{v} / \mathrm{v})$ paraformaldehyde. The specimens were then immersed in the same buffer for $24 \mathrm{~h}$ followed by dehydration in ethanol baths with increasing concentrations of ethanol $(75 \%$, $85 \%, 90 \%, 95 \%$, and $100 \%$ ). The specimens were then embedded in paraffin and placed at room temperature to allow the paraffin to solidify. The paraffin-embedded specimens were cut into slices (thickness of 6-8 $\mu \mathrm{m}$ ) using a microtome (YD-315, China). The slices were dewaxed, dehydrated, stained with haematoxylin and eosin (H.E.), and then sealed with neutral balsam. The specimens were finally observed with a light microscope (Olympus, Japan).

For electron microscopy, the gills from the control and exposed clams were immediately cut into approximately $1-\mathrm{mm}^{3}$ pieces and fixed in $2.5 \%$ glutaraldehyde $\left(4^{\circ} \mathrm{C}\right)$ for $2 \mathrm{~h}$ followed by further fixing in $1 \%$ osmium tetroxide for $2 \mathrm{~h}$. The material was contrasted with $2 \%$ uranyl acetate in $10 \%$ ethanol for $4 \mathrm{~h}$, dehydrated in an ascending series of acetone, embedded in Epon 812 Resin for $24 \mathrm{~h}$, and then incubated at $70{ }^{\circ} \mathrm{C}$ for $24 \mathrm{~h}$. The specimens were cut into $60 \mathrm{~nm}$ thick slices using an ultramicrotome (LKB-2088) and stained with uranyl acetate and lead citrate. The slices were observed with a transmission electron microscope (Hitachi - 7500, Japan).

\subsection{Sample preparation for the determination of relevant parameters}

Gill tissue extracted from each clam was homogenized on ice in $9 \mathrm{vol}\left(\mathrm{w} \mathrm{v}^{-1}\right)$ of $0.9 \%$ ice-cold physiological saline using a high throughput tissue grinder (SCIENTZ-48, China). The homogenate was then centrifuged at $4000 \times g\left(4^{\circ} \mathrm{C}\right)$ for $20 \mathrm{~min}$, and the supernatant was retained, yielding the gill extract. The levels of MDA, $\mathrm{H}_{2} \mathrm{O}_{2}, \mathrm{ASA}$, AHR and MTP $(\Delta \psi \mathrm{m})$ as well as the activities of CCO, MAO, MDH and caspases in the gill extract were then measured as described below. The protein content in the gill extract was determined by the method of Bradford (1976).

\section{4. $\mathrm{MDA}, \mathrm{H}_{2} \mathrm{O}_{2}$ content and Caspase- $-3,-8,-9$ activities}


The contents of $\mathrm{H}_{2} \mathrm{O}_{2}$, MDA (Jiancheng Biotechnology, Nanjing, China) and the activities of Caspase3,-8,-9 (Beyotime Biotechnology; Jiangsu, China) in the gill extract were assayed with commercial assay kits as described by Lin et al. (2017). The concentrations of $\mathrm{H}_{2} \mathrm{O}_{2}$ and MDA were expressed as $\mathrm{nmol} \mathrm{mg}$ protein $^{-1}$ whereas the activities of caspase $-3,-8$, and -9 were expressed as $U$ mg protein ${ }^{-1}$.

\section{5. $\mathrm{CCO}, \mathrm{MAO}$ and $\mathrm{MDH}$ activities assay}

Cytochrome oxidase (CCO), Monoamine oxidase (MAO) and malate dehydrogenase (MDH) activities in the gill extract were assayed using commercial assay kits (Jiangcheng Biotechnology, Nanjing, China). CCO assay is based on the disappearance of reduced cytochrome c (Thibault et al. 1997) and MAO assay is based on the oxidation of benzylamine to benzaldehyde (Ashafaq et al., 2014), while MDH assay is based on the reduction of oxaloacetic acid to malic acid (Childress and Somero, 1979). The activities of $\mathrm{CCO}, \mathrm{MAO}$ and $\mathrm{MDH}$ were expressed as $\mathrm{U} \mathrm{mg}$ protein $^{-1}$.

\subsection{ASA, AHR and MTP $(\Delta \psi m)$ levels assay}

The anti-superoxide anion (ASA) capacity and anti-hydroxy radical (AHR) capacity in the gill extract were determined with a superoxide anion free radical detection kit and hydroxyl free radical detection kit (Keygen Biotech, China), respectively. The ASA capacity of the tissue was expressed as $\mathrm{U} \mathrm{g}^{-1}$ protein. One ASA unit was defined as the quantity of superoxide anion free radicals required to scavenge $1 \mathrm{mg}$ of tissue protein for $40 \mathrm{~min}$ at $37^{\circ} \mathrm{C}$, which is equal to one gram of vitamin C-scavenging under the same condition. Tissue AHR capacity was expressed as $\mathrm{U} \mathrm{mg}^{-1}$ protein. One unit was defined as the amount that decreased $1 \mathrm{mmol} \mathrm{L}^{-1}$ of $\mathrm{H}_{2} \mathrm{O}_{2}$ within 1 min per milligram of tissue protein (Jiang et al., 2009).

The mitochondrial membrane potential (MTP, $\Delta \psi \mathrm{m}$ ) of the gill cells was detected using the 5, 6 -Dichloro1, 1', 3, 3'-tetraethyl-imidacarbocyanine iodide (JC-10) assay kit (Keygen Biotech., China) according to the manufacturer's instructions. In brief, the gill tissue was homogenized to disperse the gill cells, which were then incubated with $0.5 \mathrm{~mL}$ of $1: 500$ diluted $\mathrm{JC}-10$ dye solution at $37^{\circ} \mathrm{C}$ and in the dark for $30 \mathrm{~min}$. After staining, the cells were washed with $\mathrm{JC}-10$ dye buffer twice and immediately measured with a fluorescence spectrophotometer (Hitachi F-4600, Japan) using an excitation wavelength of $488 \mathrm{~nm}$ and an emission wavelength of $535 \mathrm{~nm}$.

\subsection{Statistical analysis}

All data were presented as means \pm standard errors (SE). The data were subjected to a one-way ANOVA analysis of variance. Differences among experimental groups were determined using Tukey's Multiple Comparison Test at a $P<0.05$ level of significance. The least significant difference test (LSD) was used to perform multiple comparisons among different treatment groups. All statistical analyses were done using the SPSS 20.0 (Version 20.0, Chicago, USA).

\section{Results}




\subsection{Morphological changes in gill epithelium of M. meretrix induced by Cadmium}

The gill of M. meretrix is formed by two-gill lamella (outer and the inner) which is connected via the interlamellar junction, with the gill water tube occupying the middle space of the two interlamellar junctions (Fig. 1A). Each gill lamella consists of a series of parallel gill filaments (Fig. 1B, C). The gill filaments are joined to each other by the interfilamentar junctions present preferentially in the regions where the interlamellar junctions occur (Fig. 1B). The surface of the gill filament is completely covered by cilia, called frontal, latero-frontal and lateral cilia and two or more gill filaments share the same haemolymph vessel (Fig. 1C). Contact between the external environment and the interlamellar space is achieved by occasional pores called ostrium (Fig. 1B \& 1C), located between the gill filaments. In the control group, the clams exhibited a normal health status as indicated by the organized lamellar epithelium. The gill filaments were slender and tightly arranged and were well separated from the haemolymph sinus (Fig. 1A-B). There were also abundant cilia on the surface of the gill epithelial cells (Fig. 1C-D). In the group of clams treated with $1.5 \mathrm{mg} \mathrm{L}^{-1} \mathrm{Cd}^{2+}$, no significant alteration in gill structure was revealed by histological examination (Fig. 1E \& 1F). However, the cilia of the gill epithelial cells were relatively scattered, and the number of cilia was slightly reduced (Fig. 1G, H). Exposure of the clams to increasing $\mathrm{Cd}^{2+}$ concentrations resulted in the lamellar structure of the gills exhibiting signs of structural deformation, which included the fusion of gill filament, dilated hemolymphatic sinus and degeneration of cilia (Fig. 1I-T). Clams that were exposed to $3 \mathrm{mg} \mathrm{L}^{-1} \mathrm{Cd}^{2+}$ exhibited loose interlamellar junctions in the gills (Fig. 1I) and an increasing number of hemocytes in the hemolymphatic sinus that probably caused the deformed morphology of the gill filament. There was a slight fusion between the hemolymphatic sinus and gill filaments (Fig. 1J). The number of epithelial cells decreased (Fig. 1K, double arrow), some of the gill filaments were broken and the shedding of cilia from the gill epithelial cells was more obvious (Fig. 1L, arrow and black triangle). For the clams that were exposed to $6 \mathrm{mg} \mathrm{L}^{-1}$ and $12 \mathrm{mg} \mathrm{L}^{-1} \mathrm{Cd}^{2+}$, greater histopathological changes were observed for the gills as revealed by the regression in the epithelium thickness or as an epithelium detachment (Fig. 1M-T). There was a clear fusion between the hemolymphatic sinus and gill filaments (Fig. $1 \mathrm{M}, \mathrm{N}, \mathrm{Q}, \mathrm{R},{ }^{*}$ ) as well as the presence of swelling of endothelial cells. Furthermore, a loss of epithelium thickness, some epithelium detachment with the shedding cilia, and vacuolation in the gill filament were also visible (Fig. 10, P, S, T, double arrow and black triangle).

When observed by transmission electron microscopy (TEM), the epithelial cells from the gill filaments of the control clams showed typical morphology, with intact cell membrane, nucleus and mitochondrial cristae. Moreover, the cilia also displayed well-preserved microtubules (Fig. 2A, B). In the group exposed to $1.5 \mathrm{mg} \mathrm{L}^{-1} \mathrm{Cd}^{2+}$, the morphology of the microvilli and the nucleus of the gill epithelial cells were basically intact, however, some mitochondria in the gill epithelial cells showed a loss of mitochondrial cristae (Fig. 2C, D). A number of vesicles were also evident in the cytoplasm, which were absent in the gill epithelial cells of the control clams (Fig. 2C). Damage to the cell structures increased with increasing 
$\mathrm{Cd}^{2+}$ concentrations (Fig. 2E-J), such as swollen mitochondria and a more conspicuous loss of mitochondrial cristae in the clams exposed to $3 \mathrm{mg} \mathrm{L}^{-1} \mathrm{Cd}^{2+}$ (Fig. 2E-F). These clams exhibited numerous vesiculated particles in the gill epithelial cytoplasmic space, with electron-dense particles present inside the vesicles (Fig. 2E, white double arrow). In addition, a disorganized ciliary orientation and a lack of typical microtubule were also observed in the cilia (Fig. 2E). For the clams that were treated with 6 and $12 \mathrm{mg} \mathrm{L}^{-1} \mathrm{Cd}^{2+}$, the disruption of mitochondrial cristae and a highly vesiculated cytoplasm became noticeable (Fig. 2G-J). Again, it was possible to detect highly electron-dense particles inside these vesicles (Fig. 2G-J, white double arrows). A progressive vacuolization of the nucleoplasmic content with swelling nuclear envelope (Fig. 2G-J, arrows) and a progressive disappearance of organelles were also detected in the groups treated with a higher $\mathrm{Cd}^{2+}$ concentration. Moreover, the number of lysosomes increased in the cells (Fig. 2G, I) and the number of microvilli was greatly reduced (Fig. 2G-J, black double arrows) in 6 and $12 \mathrm{mg} \mathrm{L}^{-1} \mathrm{Cd}^{2+}$-treated groups.

\subsection{Effects of $\mathrm{Cd}$ on $\mathrm{H}_{2} \mathrm{O}_{2}$ and MDA contents}

The levels of MDA in the gills of each group of $\mathrm{Cd}^{2+}$-exposed clams exhibited a significant increase $(P<$ 0.05) compared with the control group, and the increase was dependent on $\mathrm{Cd}^{2+}$ concentration (Fig. 3). The maximum level of MDA was found in the group exposed to the highest $\mathrm{Cd}^{2+}$ concentration $(12 \mathrm{mg} \mathrm{L}$ $\left.{ }^{1}\right)$ and this level was also significantly higher than the levels found in all the other $\mathrm{Cd}^{2+}$-exposed groups. However, the level of MDA found in the group exposed to $3 \mathrm{mg} \mathrm{L}^{-1} \mathrm{Cd}^{2+}$ did not differ significantly from that found in the group exposed to $6 \mathrm{mg} \mathrm{L}^{-1} \mathrm{Cd}^{2+}$ (Fig. 3).

As for the level of $\mathrm{H}_{2} \mathrm{O}_{2}$, a gradual increase caused by $\mathrm{Cd}^{2+}$ exposure was also evident, and the increase was dependent on $\mathrm{Cd}^{2+}$ concentration (Fig. 3). The highest level of $\mathrm{H}_{2} \mathrm{O}_{2}$ was found in the group exposed to the highest $\mathrm{Cd}^{2+}$ concentration, which was significantly higher than the control group and all other $\mathrm{Cd}^{2+}$-exposed groups. However, there were no significant differences among the control group, the group exposed to $1.5 \mathrm{Cd}^{2+}$ and the group exposed to $3 \mathrm{mg} \mathrm{L}^{-1} \mathrm{Cd}^{2+}$ (Fig. 3).

Thus, the levels of MDA and $\mathrm{H}_{2} \mathrm{O}_{2}$ found in the gills of $M$. meretrix exposed to $\mathrm{Cd}^{2+}$ were consistent with the fact that $\mathrm{Cd}^{2+}$ could induce the production of MDA and $\mathrm{H}_{2} \mathrm{O}_{2}$ as part of its intoxication effect.

\subsection{Effects of $\mathrm{Cd}$ on $\mathrm{CCO}, \mathrm{MAO}$ and $\mathrm{MDH}$ activities}

Cadmium inhibited the activity of CCO in the gills of clams that were exposed to this metal. Except for the group exposed to $1.5 \mathrm{mg} \mathrm{L}^{-1} \mathrm{Cd}^{2+}$, all the other $\mathrm{Cd}^{2+}$-exposed groups exhibited a significant decrease in the level of $\mathrm{COO}$ activity in the gill compared with the control group. The largest decrease was found in the group exposed to the highest $\mathrm{Cd}^{2+}$ concentration, which was also significantly lower than the levels found in all the other $\mathrm{Cd}^{2+}$-exposed groups (Fig. 4a).

The effect of $\mathrm{Cd}^{2+}$ on MAO activity in the gills of the clams seemed to vary, depending on the concentration of $\mathrm{Cd}^{2+}$ that the clams were exposed to. The highest level of MAO activity was found in 1.5 
$\mathrm{mg} \mathrm{L}^{-1} \mathrm{Cd}^{2+}$-treated group, while the lowest level was found in the gill of $12 \mathrm{mg} \mathrm{L}^{-1} \mathrm{Cd}^{2+}$-treated group (Fig. 4a). Besides, the levels of MAO activity also differed among the different $\mathrm{Cd}^{2+}$-exposed groups (Fig. 4b).

MDH activity was also significantly $(P<0.05)$ suppressed in the groups exposed to $\mathrm{Cd}^{2+}$ compared with the control group (Fig. 4c). The minimum level of MDH activity was found in the group exposed to the highest $\mathrm{Cd}^{2+}$ concentration, which was significantly different from the control group and other $\mathrm{Cd}^{2+}$ exposed groups except for the group exposed to $6 \mathrm{mg} \mathrm{L}^{-1}$. Meanwhile, no significant differences in MDH activity were observed among the groups exposed to $1.5,3$ and $6 \mathrm{mg} \mathrm{L}^{-1} \mathrm{Cd}^{2+}$ (Fig. 4c).

Taken together, the results suggested that higher $\mathrm{Cd}^{2+}$ concentrations (3-12 $\left.\mathrm{mg} \mathrm{L}^{-1}\right)$ may significantly reduce the activities of the mitochondrial marker enzymes (CCO, MAO, MDH), but the effect of $\mathrm{Cd}^{2+}$ on these enzymes tended vary depending on the enzyme.

\subsection{Effects of Cd on ASA, AHR and $\Delta \Psi m$ levels}

Cadmium appeared to cause a reduction in the levels of ASA and AHR in the gills of the clams after exposure to the metal. The levels of ASA and AHR in all $\mathrm{Cd}^{2+}$-exposed groups were lower than that of those of the control group. However, significant differences in both ASA and AHR levels were observed between the group exposed to $12 \mathrm{mg} \mathrm{L}^{-1} \mathrm{Cd}^{2+}$, which exhibited the lowest levels, and the control group (Fig. $5 \mathrm{a} \& 5 \mathrm{~b}$ ). As for the effect of $\mathrm{Cd}^{2+}$ on $\Delta \psi \mathrm{m}$, there appeared to be a significant reduction in $\Delta \psi m$ for the groups exposed to 3,6 and $12 \mathrm{mg} \mathrm{L}^{-1} \mathrm{Cd}^{2+}$ compared with the control group, with the group exposed to $12 \mathrm{mg} \mathrm{L}^{-1} \mathrm{Cd}^{2+}$ exhibiting the greatest reduction (Fig. 5c). Overall, $\mathrm{Cd}^{2+}$ seemed to reduce the antioxidant capacity and membrane potential of the mitochondria in the gill cells of $M$. meretrix exposed to the metal, with the extent of the impact being proportional to the concentration of $\mathrm{Cd}^{2+}$.

\subsection{Effects of Cd on caspase- $3,-8,-9$ activities}

The effect of $\mathrm{Cd}^{2+}$ on caspases was investigated by comparing the activity levels of caspases-3, $-8,-9$ in the gills of $\mathrm{Cd}^{2+}$-exposed clams with those in the gill of control individuals. All $\mathrm{Cd}^{2+}$-exposed clams showed significant $(P<0.05)$ increases in caspase activities compared with the control clams, with the highest level occurring at the highest $\mathrm{Cd}^{2+}$ concentration $\left(12 \mathrm{mg} \mathrm{L}^{-1}\right)$ (Fig. 6). The levels of caspase-3, -8 , -9 activities in the control group were significantly $(P<0.05)$ lower than those found in all the $\mathrm{Cd}^{2+}$ exposed groups. The results, therefore, suggested that exposure of $M$. meretrix to $\mathrm{Cd}^{2+}$ in the range of 1.5-12 $\mathrm{mg} \mathrm{L}^{-1}$ could cause the activation of caspase- $3,-8$ and -9 in the gills and the extent of activation is dependent on the concentration of the metal.

\section{Discussion}

\subsection{Oxidative damage of toxic metal to gill mitochondria}


The gills of bivalves are suitable for histopathological analysis since they consist of a simple epithelium with various cell types, in which the effects caused by toxic metals in the water can be easily observed (Trevisan et al., 2014; Zhen et al., 2018). Morphological alterations in the structure of M. meretrix gills were observed by both light microscopy (LM) and transmission electronic microscopy (TEM) (Figs. 1 \& 2). The reduced number of microvilli found on the gill epithelial cells could lead to a reduction in the ability to filter microscopic food in the water. This could then lead to physiological changes such as nutrient absorption that need to be compensated by the organism. Additionally, TEM images revealed a significant change in the structure of the mitochondria in the gill cells, such as the reduction of the cristae and mitochondrial vacuolation after exposure of the clams to 6 and $12 \mathrm{mg} \mathrm{L}^{-1} \mathrm{Cd}^{2+}$ (Fig. 2G-J), indicating that the mitochondrial were seriously damaged. Previous studies have revealed that in Ruditapes philippinarum, the mitochondria of gill epithelial cells might be the organelle targeted by Cd (Ji et al., 2019). As it is known, mitochondria are responsible for ATP production through oxidative phosphorylation and they play an essential role in the oxidative damage sustained by the cells (Meyer et al., 2013). The morphology of mitochondria is associated with the energetic state and the survival of the cells. Thus, damage to the mitochondrial morphology and internal structure will greatly affect the activity of the mitochondria, and in the case of damage inflicted by toxic metals, the metals can accumulate in the cells, and the cells will die as a result of metabolic disorder (Li et al., 2017).

Among the diverse cellular responses triggered by Cd exposure, oxidative stress (which is part of the early biological response) has been demonstrated in aquatic animals (Goswami et al., 2014; Pan et al., 2018; Park et al., 2020; Xia et al., 2016). The damage to the mitochondrial structure of gill cells in M. meretrix induced by $\mathrm{Cd}^{2+}$ will directly affect the function of the mitochondria and induce oxidative stress.

Cadmium can cause an increase in the content of intracellular ROS $\left(\mathrm{O}_{2}{ }^{\cdot-}, \mathrm{H}_{2} \mathrm{O}_{2}\right.$, and $\cdot \mathrm{OH}$, etc.), which will lead to further reactions in the cascade, such as the activation of signaling pathways, induction of apoptosis and the expression of apoptosis-related genes, indicating that oxidative stress is one of the most important mechanisms of Cd toxicity (Lin et al., 2017; Pan et al., 2018). Cadmium treatment significantly increases the level of MDA (an indicator of lipid peroxidation) in different tissues (Huang et al., 2020; Lin et al., 2017; Xia et al., 2016). The oxidative damage in gill cells induced by excessive ROS was also manifested by an increase in MDA and $\mathrm{H}_{2} \mathrm{O}_{2}$ and decrease in ASA and AHR contents (Figs. 3 \& 5). $\mathrm{Cd}^{2+}$ has been reported to induce the production of reactive oxygen species (ROS) by interfering with the mitochondrial electron transport chain, consequently causing damage to proteins and lipids, thereby impairing mitochondrial function and increasing mitochondrial membrane permeability (Kim et al., 2015). Mitochondria are the main site of ROS generation, but at the same time, they are also the most sensitive targets to the action of ROS (Pan et al. 2018; Zorov et al., 2014). Once mitochondria have been challenged by toxins, a series of responsive proteins, such as $\mathrm{CCO}, \mathrm{MDH}$ and MAO, will be differentially expressed to safeguard the function of the mitochondria (Meyer et al., 2013; Valera-Alberni and Canto, 2018). MDH, an essential enzyme of the tricarboxylic acid (TCA) cycle, is located in the mitochondrial matrix. It catalyzes the formation of malic acid into oxaloacetic acid, which can scavenge $\mathrm{H}_{2} \mathrm{O}_{2}$ and effectively prevent $\cdot \mathrm{OH}$ from damaging DNA ( $\mathrm{Li}$ et al., 2017). MAO and CCO are located on the outer and inner membrane of the mitochondria, respectively (Achard-Joris et al., 2006). MAO is a flavo-enzyme 
involved in the oxidative deamination of amine neurotransmitters (Abdelouahab et al., 2010), while CCO can shield against the metal-induced superoxide stress to maintain a redox balance in the mitochondrial chambers (Achard-Joris et al., 2006; Liu et al., 2013). The activities of MDH, CCO and MAO in the mitochondria of gill cells were inhibited by $\mathrm{Cd}^{2+}$ in a concentration-dependent manner (Fig. 4). Reduced levels of $\mathrm{MDH}, \mathrm{CCO}$ and $\mathrm{MAO}$ activities might, in turn, lead to reduced metabolic capacity and scavenging of free radicals $\left(\mathrm{H}_{2} \mathrm{O}_{2}, \cdot \mathrm{OH}\right)$ generated by $\mathrm{Cd}^{2+}$ (Das et al., 2018; Li et al., 2017). Zhang et al. (2001) suggested that $\mathrm{CCO}$ inhibitors can cause a rapid and severe depletion of cellular ATP content, resulting in acute cell death. In M. meretrix, Cd may induce the production of ROS in the gills by interfering with the electron transport chain, destroying the membrane structure of mitochondria, affecting mitochondrial function and ultimately leading to apoptosis. A decrease the level of enzyme activities of the mitochondrial respiratory chain is closely related to the energy metabolism of the mitochondria, which ultimately leads to apoptosis (Mamos et al., 2016).

\subsection{Endogenous mitochondrial apoptosis pathways induced by toxic metal}

Mitochondria are site for the initiation of apoptosis and calcium signal regulation (Cong et al., 2019). Mitochondrial membrane potential (MMP, $\Delta \psi \mathrm{m}$ ), caspase-9, $-8,-3$, and cytochrome $\mathrm{c}$ (Cyt c) are known to be the major factors in mitochondrial associated apoptosis (Düssmann et al., 2017; Kim et al., 2015). Caspase-3 is the most well-known downstream effector caspase and it is activated through cleavage, which converts the enzyme into the active form (cleaved caspase-3) that facilitates apoptosis (Zhao et al., 2015). In this study, the activities of caspases $-3,-8$ and -9 in the gill cells increased significantly and dose-dependently following exposure of the clams to $\mathrm{Cd}^{2+}$ (Fig. 6), suggesting that the enhanced activation of caspase-3 by $\mathrm{Cd}^{2+}$ caused the apoptosis observed in the gill of $M$. meretrix. The results were consistent with the findings of Wang et al. (2012), which demonstrated that caspase activation is involved in the process of Cd-induced apoptosis in Sinopotamon henanense. Yuan et al. (2018) suggested that decreased $\Delta \psi \mathrm{m}$, released of Cyt $\mathrm{c}$ from mitochondria into the cytoplasm and increased caspase-3 and caspase -9 activities can directly lead to apoptosis. A collapsing $\Delta \psi m$ may be an early event in the apoptotic process, and $\Delta \psi \mathrm{m}$ is the premise index for the detection of apoptosis (Suhaili et al., 2017; Xu et al., 2016; Yuan et al., 2018). The negative effect of $C d$ on $\Delta \psi m$ has been frequently reported in cells or isolated mitochondria (Belyaeva et al., 2008; Liu et al., 2013). Srdic-Rajic et al. (2011) also observed a significant loss of $\Delta \psi \mathrm{m}$ in human cervix carcinoma cells (HeLa) and human endothelial cells (EA. hy 926 cells) following $3 \mathrm{~h}$ of exposure to $\mathrm{Cd}^{2+}$ and $\mathrm{Zn}^{2+}$ complexes or $\mathrm{Cd}^{2+}$ and $\mathrm{Ni}^{2+}$ complexes. Consistently, a decrease in $\Delta \psi \mathrm{m}$ was also observed in $M$. meretrix exposed to higher concentration ( 6 and $12 \mathrm{mg} \mathrm{L}^{-1}$ ) of $\mathrm{Cd}^{2+}$ (Fig. 5), indicating that Cd possibly enhanced the release of Cyt c from mitochondria to cytoplasm, therefore, leading to mitochondrial dysfunction. Our data were consistent with previous data on Ruditapes philippinarum where $\mathrm{Cd}$ was found to induce an increase in the production of extracellular ROS along with a decrease in $\Delta \psi \mathrm{m}$ (Ji et al., 2019). In summary, exposure of M. meretrix to $\mathrm{Cd}^{2+}$ caused substantial damage to the gills, leading to the loss of $\Delta \psi \mathrm{m}$, induction of Cyt $\mathrm{c}$ release from the mitochondria to the cytoplasm and the consequent activation of caspases, with the eventual 
triggering of the mitochondria-dependent apoptotic signaling pathway. Since the gill cells underwent apoptosis as a result of stress induced by $\mathrm{Cd}^{2+}$-toxicity, apoptosis is considered to proceed via the intrinsic pathway, which is mediated by the B-cell lymphoma $2(\mathrm{Bcl}-2)$ family of proteins. The implication of several transcription factors, such as Bax/Bcl-2, and their regulation of gene(s) involved in the apoptosis of M. meretrix gill cells will therefore, be a subject of further study.

\section{Abbreviations}

AHR: anti-hydroxy radical; ASA: anti-superoxide anion; CCO: cytochrome oxidase; Cyt c: cytochrome c; $\mathrm{H}_{2} \mathrm{O}_{2}$ : hydrogen peroxide; $\mathrm{MAO}$ : monoamine oxidase; MDA: malondialdehyde; $\mathrm{MDH}$ : malate dehydrogenase; $\operatorname{MTP}(\Delta \psi \mathrm{m})$ : mitochondrial membrane potential; $\mathrm{O}_{2}{ }^{--}$: superoxide radical; $\cdot \mathrm{OH}$ : hydroxide radical; ROS: reactive oxygen species.

\section{Declarations}

\section{Data availability}

All authors guarantee that all data and materials support our published claims and the Data are available by contacting XP Ying (xpying2008@wzu.edu.cn).

\section{Compliance with ethical standards}

\section{Conflict of interest}

There is no conflict of interest for any of the submitting authors in reference to the submitted material and we agree to the names being included in the list of authors, and, in the given order of priority.

\section{Ethical approval}

All applicable international, national, and/or institutional guidelines for the care and use of animals were followed.

\section{Consent to publish}

All the authors are in agreement with the publishment.

\section{Publisher's note}

Springer Nature remains neutral with regard to jurisdictional claims in published maps and institutional affiliations.

\section{Author contributions}


All authors conceived and designed the study. JW and WD performed the study, analyzed the data and drafted the manuscript. TZ and BB performed the sample collection, sample processing and extraction. $A C$ and $X Y$ provided experimental supervision and approved the final manuscript..

\section{Funding}

This study was supported by the National Natural Science Foundation of China under Grant number 32071514 (to YXP), the Nature Science Foundation of Zhejiang Province (CN) under Grant number LY18C030005 (to YXP), and the Graduate Innovation Program of Wenzhou University under Grant number 3162019005 (to WJH).

\section{References}

1. Abdelouahab N, Guy H, Suvorov A, Foliguet B, Goua V, Debotte G, Sahuquillo J, Charles MA, Takser L (2010) Monoamine oxidase activity in placenta in relation to manganese, cadmium, lead, and mercury at delivery. Neurotoxicology and Teratology 32: 256-261

2. Achard-Joris M, Gonzalez P, Marie V, Baudrimont M, Bourdineaud JP (2006) Cytochrome c oxydase subunit I gene is up-regulated by cadmium in freshwater and marine bivalves. BioMetals 19: 237244

3. Adiele RC, Stevens D, Kamunde C (2011) Cadmium- and calcium-mediated toxicity in rainbow trout (Oncorhynchus mykiss) in vivo: interactions on fitness and mitochondrial endpoints. Chemosphere 85: $1604-1613$

4. Alyahya H, El-Gendy AH, FaSlabyraj SA, El-Hedeny M (2011) Evaluation of heavy metal pollution in the arabian gulf using the clam Meretrix meretrix Linnaeus, 1758. Water Air Soil Pollution 214: 499507

5. Ashafaq M, Varshney L, Khan MHA, Salman M, Naseem M, Wajid S, Parvez S (2014) Neuromodulatory effects of hesperidin in mitigating oxidative stress in streptozotocin induced diabetes. Biomed Res. Int. 1-9. doi. 10. 1155 /2014 /249031

6. Bhansali S, Bhansali A, Dhawan V (2017) Favourable metabolic profile sustains mitophagy and prevents metabolic abnormalities in metabolically healthy obese individuals. Diabetol. Metab. Syndr. 9, 99. doi: 10.1186 /s13098-017-0298-x

7. Belyaeva EA, Dymkowska D, Wieckowski MR, Wojtczak L (2008) Mitochondria as an important target in heavy metal toxicity in rat hepatoma AS-30D cells. Toxicol. Appl. Pharmacol. 231: 34-42

8. Bradford MM (1976) A rapid and sensitive method for the quantitation of microgram quantities of protein utilizing the principle of protein-dye binding. Anal. Biochem. 72: 248-254

9. Capriello T, Grimaldi MC, Cofone R, D'Aniello S, Ferrandino I (2019) Effects of aluminum and cadmium on hatching and swimming ability in developing zebrafish. Chemosphere 222: 243-249

10. Chandurvelan R, Marsden ID, Glover CN, Gaw S (2015) Assessment of a mussel as a metal bioindicator of coastal contamination: relationships between metal bioaccumulation and multiple 
biomarker responses. Sci. Total Environ. 511: 663-675

11. Chen MX, Zhou JY, Lin JH, Tang HC, Shan YF, Chang AK, Ying XP (2020) Changes in oxidative stress biomarkers in Sinonovacula constricta in response to toxic metal accumulation during growth in an aquaculture farm. Chemosphere 248, doi: 10. 1016 /j. chemosphere. 2020.125974

12. Childress JJ, Somero GN (1979) Depth -related enzymic activities in muscle, brain and heart of deep living pelagic marine teleosts. Mar. Biol., 52 (3): 273-283

13. Cong M, Wu HF, Cao TF, Ji CL, Lv JS (2019) Effects of ammonia nitrogen on gill mitochondria in clam Ruditapes philippinarum. Environmental Toxicology and Pharmacology 65: 46-52

14. Das D, Das P, Moniruzzaman M, Sarkar MP, Mukherjee J, Chakraborty SB (2018) Consequences of oxidative damage and mitochondrial dysfunction on the fatty acid profile of muscle of Indian Major Carps considering metal toxicity. Chemosphere 207: 385-396

15. Đukić-Ćosić D, Baralić K, Javorac D, Buha Đorđević A, Bulat Z (2020) An overview of molecular mechanisms in cadmium toxicity. Current Opinion in Toxicology 19: 56-62

16. Düssmann H, Perez-Alvarez S, Anilkumar U, Papkovsky DB (2017) Single-cell time-lapse imaging of intracellular $\mathrm{O}_{2}$ in response to metabolic inhibition and mitochondrial cytochrome-c release. Cell Death Dis. 8 (6), e2853. doi: 10. 1038/ cddis. 2017. 247

17. Feng L, Zhao S, Chen GF, Jiang WD, Liu Y, Jiang J, Hu K, Li SH (2014) Antioxidant status of serum, muscle, intestine and hepatopancreas for fish fed graded levels of biotin. Fish Physiol Biochem 40: 499-510

18. Fitzgerald JC, Ufer C, De Girolamo LA, Kuhn H, Billett EE (2007) Monoamine oxidase-A modulates apoptotic cell death induced by staurosporine in human neuroblastoma cells. J. Neurochem. 103: 2189-2199

19. Goswami P, Hariharan G, Godhantaraman N, Munuswamy N (2014) An integrated use of multiple biomarkers to investigate the individual and combined effect of copper and cadmium on the marine green mussel (Perna viridis). Journal of Environmental Science and Health, Part A 49: 1564-1577

20. Huang Y, Tang HC, Jin JY, Fan MB, Chang AK, Ying XP (2020) Effects of waterborne cadmium exposure on its internal distribution in Meretrix meretrix and detoxification by metallothionine and antioxidant enzymes. Frontiers in Marine Science doi: 10. 3389/ fmars. 2020. 00502

21. Ji CL, Lu Z, Xu LL, Cong M, Shan XJ, Wu HF (2019) Evaluation of mitochondrial toxicity of cadmium in clam Ruditapes philippinarum using iTRAQ-based proteomics. Environ. Pollut. 251: 802-810

22. Jiang W, Feng L, Liu Y, Jiang J, Zhou X (2009) Myo-inositol prevents oxidative damage, inhibits oxygen radical generation and increases antioxidant enzyme activities of juvenile Jian carp (Cyprinus carpio var. Jian). Aquac. Res. 40: 1770-1776

23. Jing WX, Lang L, Lin ZG, Liu N, Wang L (2019) Cadmium bioaccumulation and elimination in tissues of the freshwater mussel Anodonta woodiana. Chemosphere 219: 321-327

24. Kim HS, Kim YJ, Seo YR (2015) An overview of carcinogenic heavy metal: molecular toxicity mechanism and prevention. J. Cancer Prev. 20 (4): 232-240 
25. Li J, Huang Q, Long X, Guo X, Sun X, Jin X, Li Z, Ren T, Yuan P, Huang X, Zhang H, Xing J (2017) Mitochondrial elongation-mediated glucose metabolism reprogramming is essential for tumour cell survival during energy stress. Oncogene 36: 4901-4912

26. Lin Y, Huang JJ, Dahms HU, Zhen JJ, Ying XP (2017) Cell damage and apoptosis in the hepatopancreas of Eriocheir sinensis induced by cadmium. Aquatic Toxicology 190: 190-198

27. Liu DM, Yang J, Li YJ, Zhang M, Wang L (2013) Cd-induced apoptosis through the mitochondrial pathway in the hepatopancreas of the freshwater crab Sinopotamon henanense. PLoS One 8 (7): $668-770$

28. Mamos T, Wattier R, Burzyński A, Grabowski M (2016) The legacy of a vanished sea: a high level of diversifification within a European freshwater amphipod species complex driven by 15 My of Paratethys regression. Mol. Ecol. 25 (3): 795-810

29. Marasinghe Wadige CPM, Taylor AM, Krikowa F, Lintermans M, Maher WA (2017) Exposure of the freshwater bivalve Hyridella australis to metal contaminated sediments in the field and laboratory microcosms: metal uptake and effects. Ecotoxicology 26 (3): 415-434

30. Meyer JN, Leung MCK, Rooney JP, Sendoel A, Hengartner MO, Kisby GE, Bess AS (2013) Mitochondria as a target of environmental toxicants. Toxicol. Sci. 134: 1-17

31. Pan YX, Luo Z, Zhuo MQ, Wei CC, Chen GH, Song YF (2018) Oxidative stress and mitochondrial dysfunction mediated $\mathrm{Cd}$-induced hepatic lipid accumulation in zebrafish Danio rerio. Aquat. Toxicol. 199: $12-20$

32. Park K, Han EJ, Ahn G, Kwak IS (2020) Effects of combined stressors to cadmium and high temperature on antioxidant defense, apoptotic cell death, and DNA methylation in zebrafish (Danio rerio) embryos. Science of the Total Environment 716, 137130. doi: 10. 1016/ j. scitotenv. 2020. 137130

33. Srdic-Rajic T, Zec M, Todorovic T, Andelkovic K, Radulovic S (2011) Non-substituted N-heteroaromatic selenosemicarbazone metal complexes induce apoptosis in cancer cells via activation of mitochondrial pathway. European Journal of Medicinal Chemistry 46: 3734-3747

34. Suhaili SH, Karimian H, Stellato M, Lee TH, Aguilar MI (2017) Mitochondrial outer membrane permeabilization: a focus on the role of mitochondrial membrane structural organization. Biophys. Rev. 9: 443-457

35. Thibault M, Blier PU, Guderley H (1997) Seasonal variation of muscle metabolic organization in rainbow trout (Oncorhynchus mykiss). Fish Physiology and Biochemistry 16 (2): 139-155

36. Trevisan R, Delapedra G, Mello DF, Arl M, Schmidt ÉC, Meder F, Monopoli M, Cargnin-Ferreira E, Bouzon ZL, Fisher AS, Sheehan D, Dafre AL (2014) Gills are an initial target of zinc oxide nanoparticles in oysters Crassostrea gigas, leading to mitochondrial disruption and oxidative stress. Aquatic Toxicology 153: 27-38

37. Valera-Alberni M, Canto C (2018) Mitochondrial stress management: a dynamic journey. Cell Stress 2: $253-274$ 
38. Wallace DR, Spandidos DA, Tsatsakis A, Schweitzer A, Djordjevic V, Djordjevic AB (2019) Potential interaction of cadmium chloride with pancreatic mitochondria: implications for pancreatic cancer. Int. J. Mol. Med. 44: 145-156

39. Wan R, Meng FP, Su EP, Fu WC, Wang Q (2018) Development of a classification scheme for evaluating water quality in marine environment receiving treated municipal effluent by an integrated biomarker approach in Meretrix meretrix. Ecological Indicators 93: 697-703

40. Wang JX, Wang Q, Li JR, Shen QQ, Wang F, Wang L (2012) Cadmium induces hydrogen peroxide production and initiates hydrogen peroxide-dependent apoptosis in the gill of freshwater crab, Sinopotamon henanense. Comparative Biochemistry and Physiology, Part C 156: 195-201

41. Wu JP, Li MH, Chen JS, Chung SY, Lee HL (2015) Disturbances to neurotransmitter levels and their metabolic enzyme activity in a freshwater planarian exposed to cadmium. Neuro Toxicology 47: $72-$ 81

42. Xia LP, Chen SH, Dahms HU, Ying XP, Peng X (2016) Cadmium induced oxidative damage and apoptosis in the hepatopancreas of Meretrix meretrix. Ecotoxicology 25: 959-969

43. Xu ZY, Zheng MX, Zhang Y, Cui XZ, Yang SS, Liu RL, Li S, Lv QH, Zhao WL, Bai R (2016) The effect of the mitochondrial permeability transition pore on apoptosis in Eimeria tenella host cells. Poultry Sci. 95 (10): 2405-2413

44. Yuan Y, Zhang YJ, Zhao SW, Chen J, Yang JL, Wang T, Zou H, Wang Y, Gu JH, Liu XZ, Bian JC Liu ZP (2018) Cadmium-induced apoptosis in neuronal cells is mediated by Fas/FasL-mediated mitochondrial apoptotic signaling pathway. Sci Rep 8 (1), 8837. https: // doi. Org / 10. 1038 / s 41598 - $018-27106-9$

45. Zhang JG, Tirmenstein MA, Nicholls-Grzemski FA, Fariss MW (2001) Mitochondrial electron transport inhibitors cause lipid peroxidation-dependent and -independent cell death: protective role of antioxidants. Arch. Biochem. Biophys. 393: 87-96

46. Zhang JF, Gao XL (2015) Heavy metals in surface sediments of the intertidal Laizhou Bay, Bohai Sea, China: Distributions, sources and contamination assessment. Marine pollution bulletin, 98(1-2): 320-327

47. Zhao H, Liu W, Wang Y, Dai NJ, Yuan Y, Liu X, Bian J, Liu ZP (2015) Cadmium induces apoptosis in primary rat osteoblasts through caspase and mitogen-activated protein kinase pathways. J. Vet. Sci. 16: $297-306$

48. Zhen JJ, Ye FY, Wang D, Ni XY, Ying XP (2018) Effect of cadmium on ultrastructure of gill epithelial cells in clam Meretrix meretrix. Fisheries science 37(4): 469-474

49. Zorov DB, Juhaszova M, Sollott SJ (2014) Mitochondrial reactive oxygen species (ROS) and ROSinduced ROS release. Physiol. Rev. 94 (3): 909-950

\section{Figures}



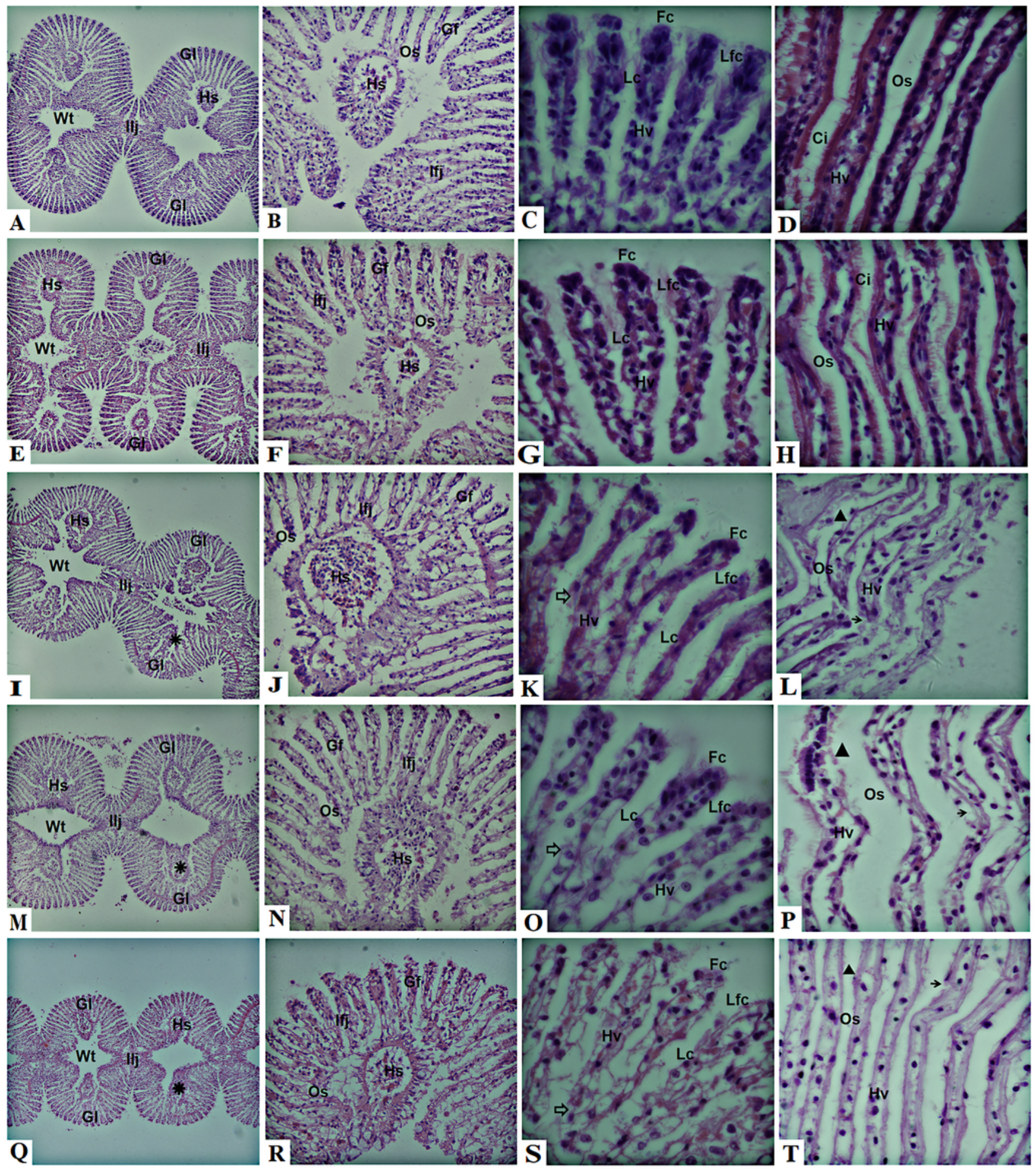

\section{Figure 1}

Histological sections analysis of M. meretrix gills exposed to different $C d 2+$ concentrations. A-D, Control group; E-T, Cd2+-exposed groups. These groups were exposed to Cd2+ at $1.5 \mathrm{mg} \mathrm{L}-1(\mathrm{E}-\mathrm{H}) ; 3 \mathrm{mg} \mathrm{L}-1$ Cd2+ (I-L); $6 \mathrm{mg} \mathrm{L}-1$ (M-P); $12 \mathrm{mg} \mathrm{L}-1$ (Q-T). A, E, I, M, Q: cross-section of the gills at $\times 100$ magnification showing two-gill lamella (GI), hemolymphatic sinus (Hs), interlamellar junction (Ilj) and gill water tube $(\mathrm{Wt}) ; \mathrm{B}, \mathrm{F}, \mathrm{J}, \mathrm{N}, \mathrm{R}$ : cross-section of gill lamella $\times 400$ magnification showing hemolymphatic sinus (Hs), gill 
filaments (Gf), interfilamental junction(Ifj) and ostrium (Os) ; C, G, K, O, S: the cross section of gill filaments $\times 1000$ magnification showing frontal cilia (Fc), latero-frontal cilia (LfC), lateral cilia (LC) and haemolymph vessel $(\mathrm{Hv}) ; \mathrm{D}, \mathrm{H}, \mathrm{L}, \mathrm{P}, \mathrm{T}$ : longitudinal section of the gill filaments $\times 1000$ magnification showing cilia (Ci), haemolymph vessel (Hv) and ostrium (Os).

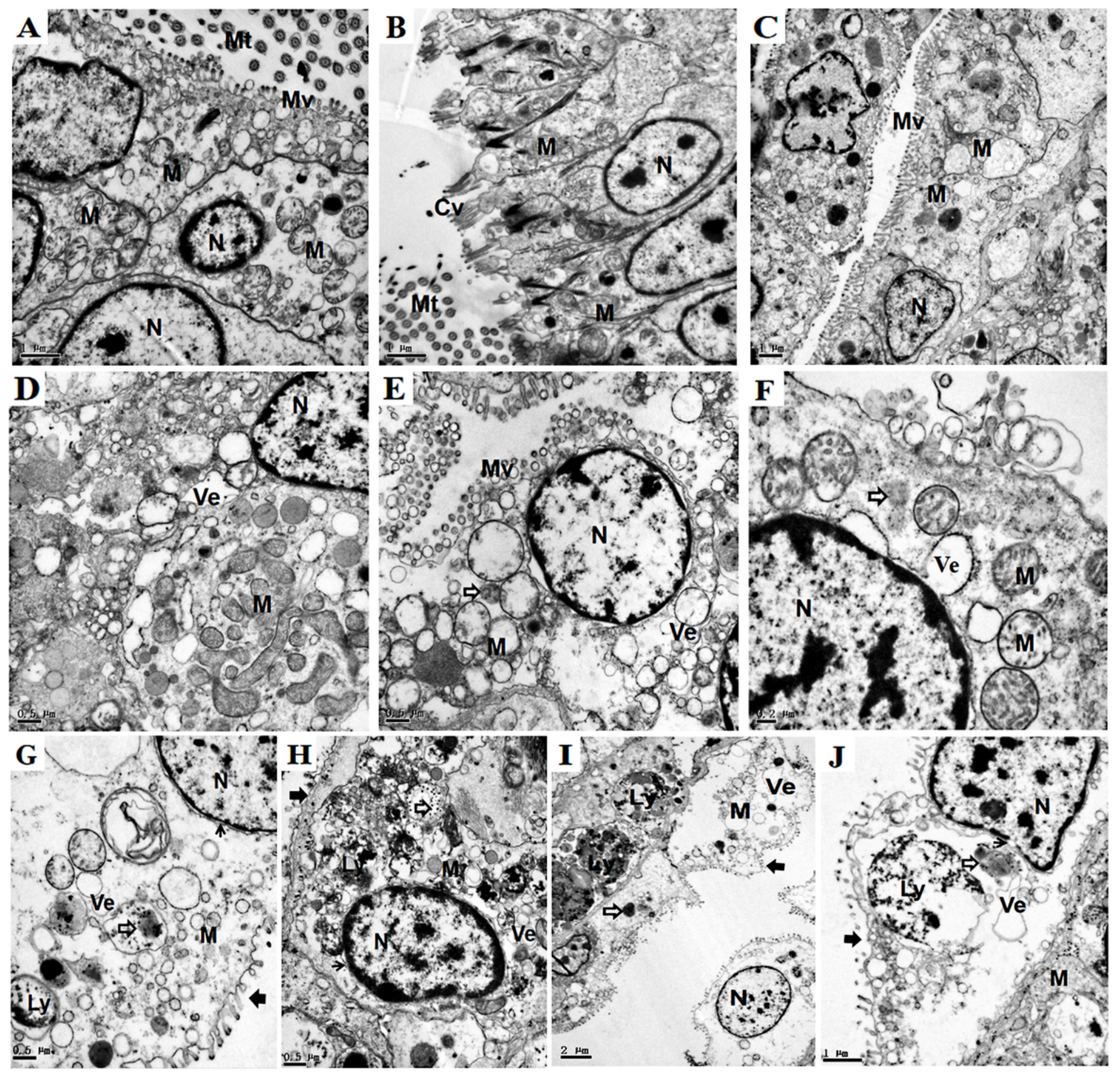

Figure 2

Ultrastructure analysis of the gills of $\mathrm{M}$. meretrix following exposure to different $\mathrm{Cd} 2+$ concentrations. Control group (A-B, Bar = $1 \mu \mathrm{m}) ; 1.5 \mathrm{mg} \mathrm{L}-1 \mathrm{Cd} 2+$ group (C-D, Bar: C $=1 \mu \mathrm{m}, \mathrm{D}=0.5 \mu \mathrm{m}) ; 3 \mathrm{mg} \mathrm{L}-1 \mathrm{Cd} 2+$ group (E-F, Bar: $E=0.5 \mu \mathrm{m}, \mathrm{F}=0.2 \mu \mathrm{m}) ; 6 \mathrm{mg} \mathrm{L}-1 \mathrm{Cd} 2+\operatorname{group}(\mathrm{G}-\mathrm{H}, \mathrm{Bar}=0.5 \mu \mathrm{m}) ; 12 \mathrm{mg} \mathrm{L}-1 \mathrm{Cd} 2+$ group 
(I-J, Bar: I = $2 \mu \mathrm{m}, \mathrm{J}=1 \mu \mathrm{m})$. Ci: cilia; Ly: Iysosomes; M: mitochondrion; Mt: microtubules; Mv: microvilli; N: nucleus; Ve: vesicle.

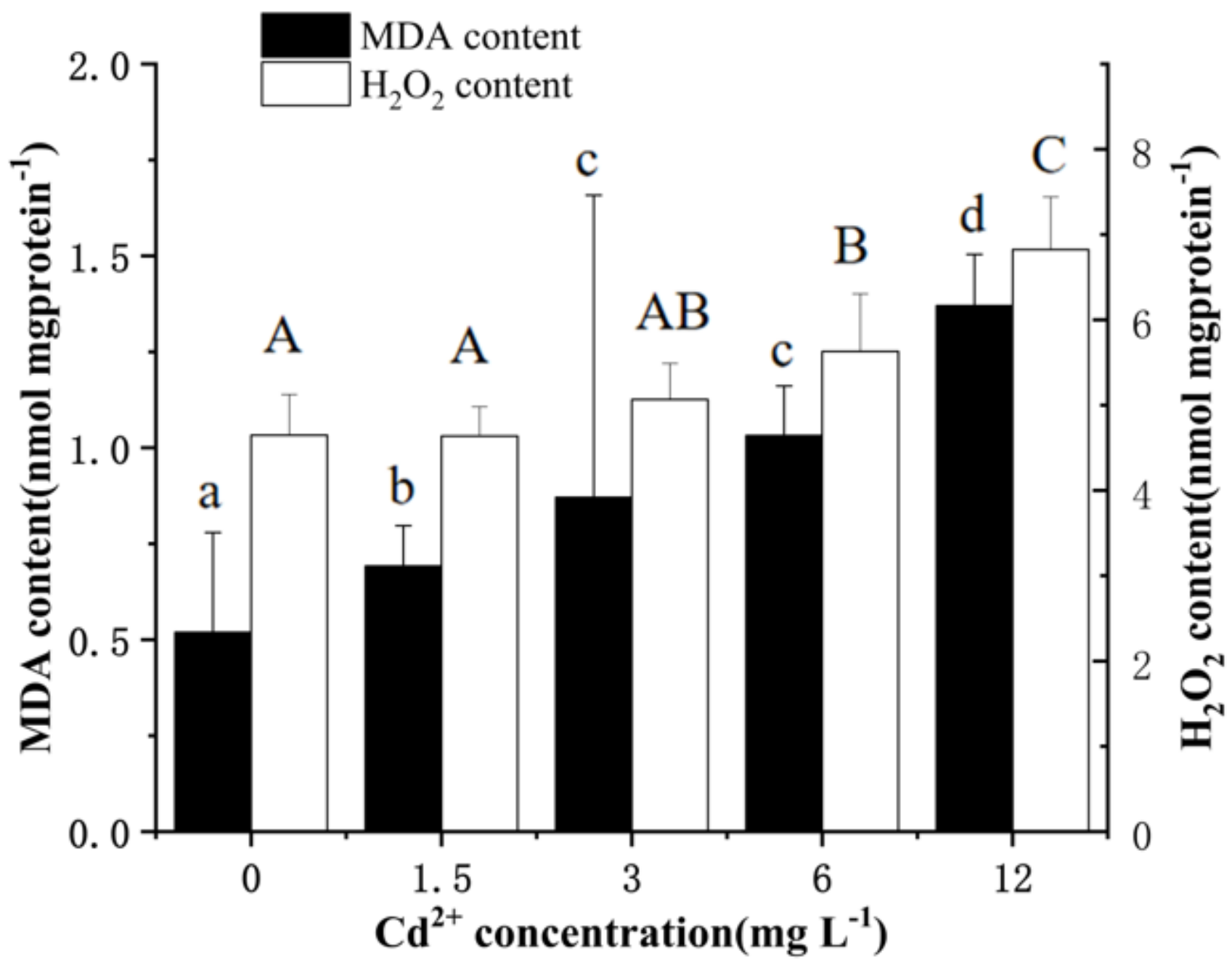

Figure 3

Effect of $\mathrm{Cd} 2+$ on the levels of MDA (black pillars) and H2O2 (white pillars) in M. meretrix gills. Different letters indicate significant $(P<0.05)$ differences among groups as revealed by Tukey's post-hoc multiple comparison tests; uppercase represents $\mathrm{H} 2 \mathrm{O} 2$ and the lowercase represents MDA; Data are expressed as mean $\pm S E(n=6)$. 

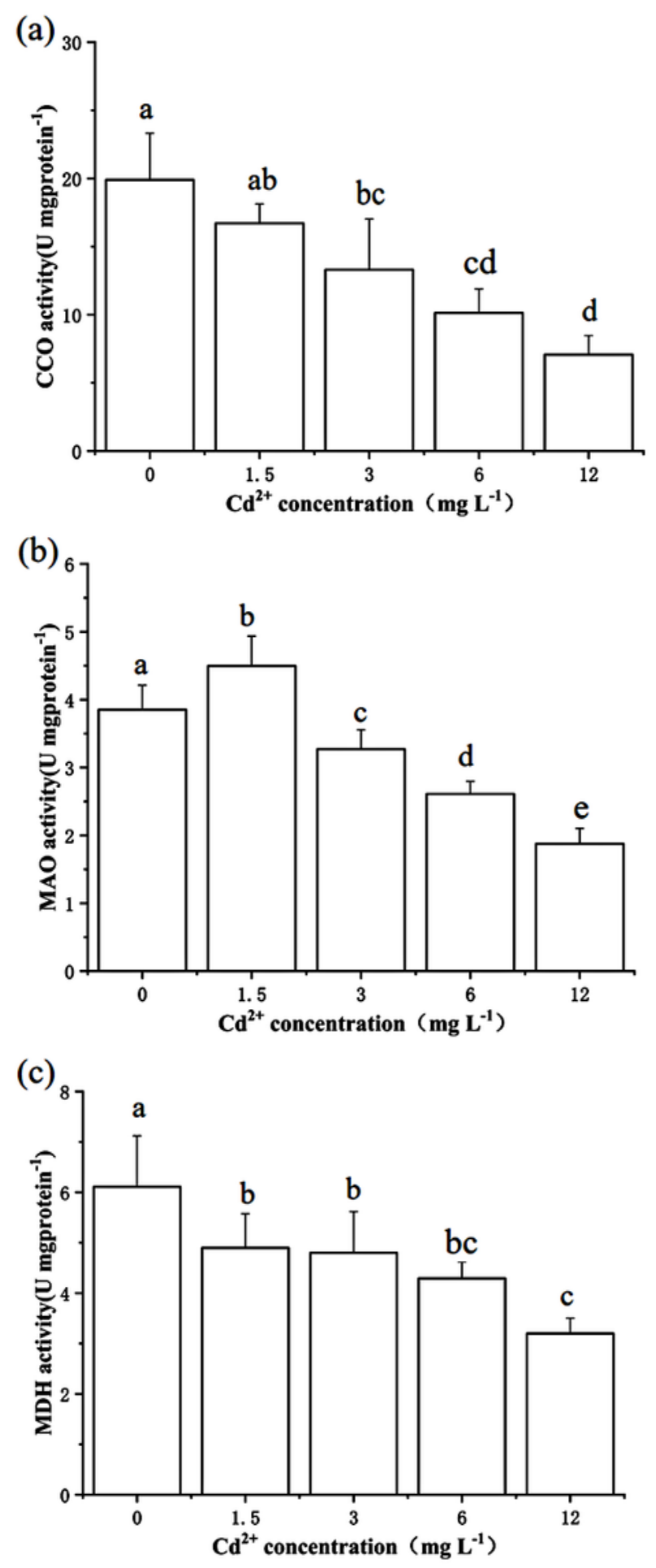

Figure 4

Effect of $\mathrm{Cd} 2+$ on the activities of $\mathrm{CCO}, \mathrm{MAO}$ and $\mathrm{MDH}$ in $\mathrm{M}$. meretrix gill Different letters indicate significant $(P<0.05)$ differences among groups as revealed by Tukey's post-hoc multiple comparison tests; Data are expressed as mean \pm SE $(n=6)$. 

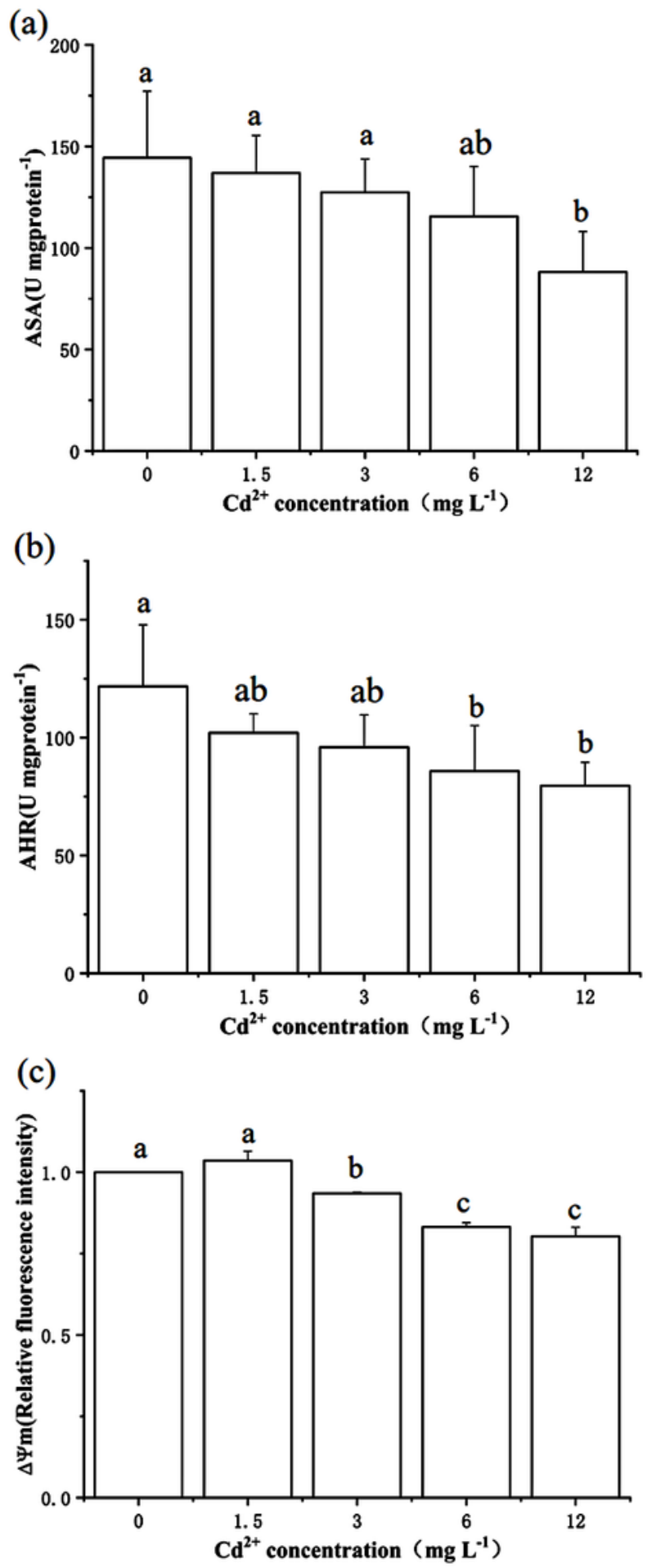

Figure 5

Effect of Cd2+ on the levels of ASA (a), AHR (b) and $\Delta \psi \mathrm{m}(\mathrm{c})$ in M. meretrix gills. Different letters indicate significant $(P<0.05)$ differences among groups as revealed by Tukey's post-hoc multiple comparison tests; Data are expressed as mean \pm SE $(n=6)$. 

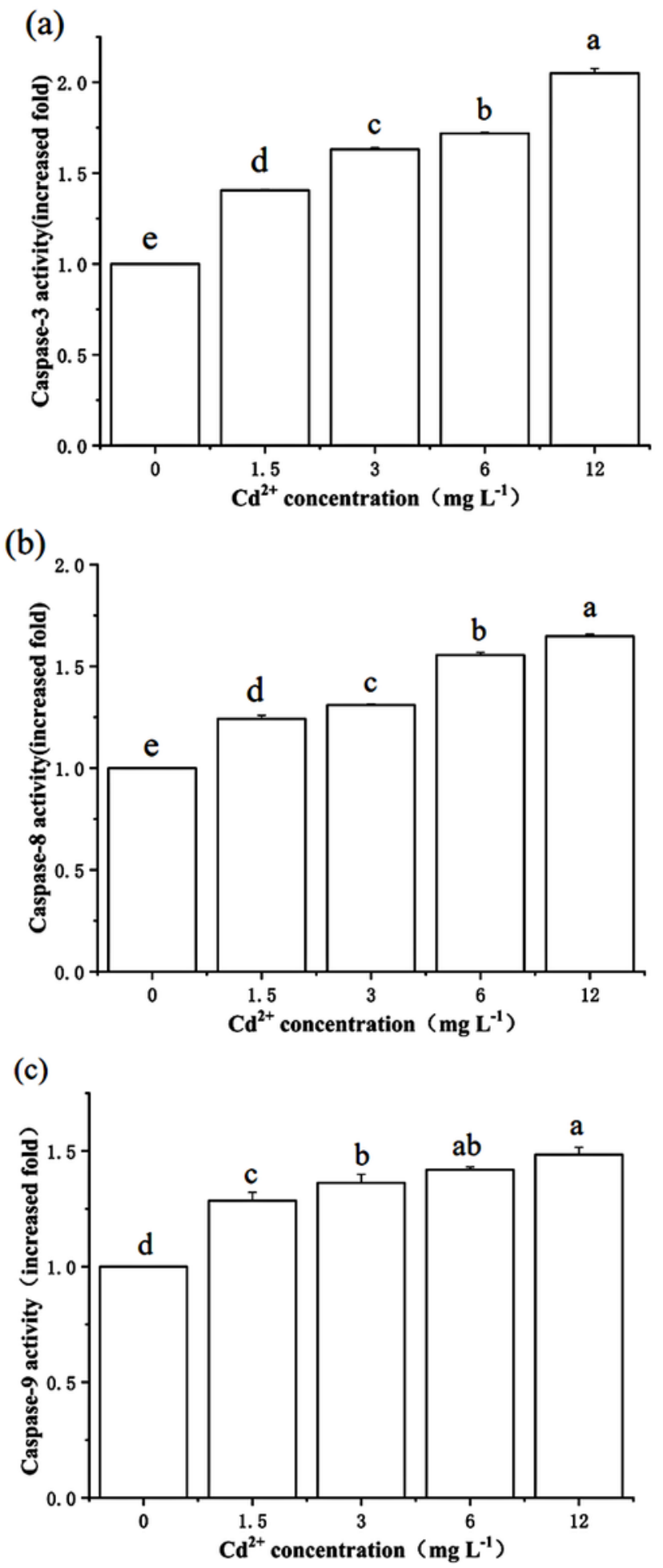

Figure 6

Effect of Cd2+ on the activities of caspase-3 (a), caspase-8 (b), caspase-9 (c) in M. meretrix gills. Different letters indicate significant $(P<0.05)$ differences among groups as revealed by Tukey's post-hoc multiple comparison tests; Data are expressed as mean $\pm S E(n=6)$. 